\title{
CYTOTOXICITY AND IN-VITRO ANTIVIRAL ACTIVITY OF LECTIN FROM CROCUS VERNUS L. AGAINST POTATO VIRUS Y
}

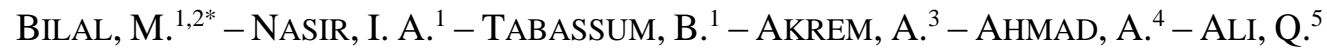 \\ ${ }^{1}$ Centre of Excellence in Molecular Biology, University of the Punjab, 87-West Canal Road \\ Thokar Niaz Baig, Lahore 53700, Pakistan \\ ${ }^{2}$ Centre for Applied Molecular Biology, University of the Punjab, 87-West Canal Bank Road, \\ Thokar Niaz Baig, Lahore 53700, Pakistan \\ ${ }^{3}$ Department of Botany, Institute of Pure and Applied Biology, Bahauddin Zakariya University, \\ Multan, Pakistan \\ ${ }^{4}$ Institute of Genetics and Developmental Biology, University of Chinese Academy of Sciences, \\ Beijing, China \\ ${ }^{5}$ Institute of Molecular Biology and Biotechnology, University of Lahore, Lahore, Pakistan \\ *Corresponding author \\ e-mail: bilal.camb@pu.edu.pk
}

(Received $2^{\text {nd }}$ Sep 2019; accepted $4^{\text {th }}$ Dec 2019)

\begin{abstract}
Plant lectins are the potential proteins that specifically bound and cross linked with carbohydrates and target particular glycans present on the cell surface of viruses through a pathway termed as a lectin activation pathway. They have a role in plant defense system. In this study, we evaluated anti- $P V Y$ (potato virus $\mathrm{Y}$ ) activity of plant derived lectin in in-vitro assay. A tetramer lectin was isolated from the corms of Crocus vernus and purified to sub fractions through ammonium sulfate precipitation, dialysis, filtration on the PD 10 column, cation exchange chromatography on SP-Sepharose gel. In-silico studies predicted stable interaction between Crocus vernus lectin (CVL) and targeted protein of $P V Y$. Cytotoxicity tests performed on HepG2 cells indicated IC50 value for CVL was $770 \mu \mathrm{g} / \mathrm{ml}$. The IC50 values indicated the safe limit and non-cytotoxic effect of the CVL extract and worth for further testing. The hemagglutination activity of CVL against the rabbit erythrocytes was revealed to be $100 \mu \mathrm{g} / \mathrm{ml}$. The anti- $P V Y$ activity displayed in the CVL lectin was evaluated through quantitative realtime PCR assay. It was revealed that CVL was effective against targeted gene of $P V Y$ at 30,60 and $90 \mu \mathrm{g} / \mathrm{ml}$ concentration and up to $100 \%$ inhibition of the $P V Y$ mRNA was achieved in all three tested concentrations in comparison with control. Our results clearly indicate the CVL gene can be a used for transformation studies in potato to control the potato virus $\mathrm{Y}$ as an effective tool, in the future.
\end{abstract}

Keywords: Crocus vernus lectin $(C V L)$, potato virus $Y$, real time $P C R$, coat protein, antiviral activity, in silico analysis

\section{Introduction}

Mannose-binding lectins prove to be of immense importance and potency in preventing and treating virus-mediated infections as they specifically target particular glycans present on the cell surface which are required by virus for entry (Balzarini et al., 2007). A variety of lectins have already been reported from different organisms belonging to a wide range of taxonomical groups, including plants, animals, bacteria, fungus and algae (Golotin et al., 2019; Singh et al., 2018; Sreeramulu et al., 2018; Muslim et al., 2018; Zhang et al., 2017a). The structure, efficacy and specificity of these lectins may vary from source to source. Till to date, lectins have been published from different plant families, including Alliaceae, Amaryllidaceae, Araceae, Bromeliaceae, 
Iridaceae, Liliaceae, and Orchidaceae and their activity has been reported against Human Immunodeficiency Virus, Simian Immunodeficiency Virus and Feline Immunodeficiency Virus (Lam and Ng, 2001; Davidson et al., 2000).

Potato virus $Y(P V Y)$ belongs to the genus Potyvirus of the Potyviridae family (Kitajima et al., 1997). Worldwide a number of crops are affected in a severe damaging way by this virus, especially solanaceous plants like potato (Solanumtuberosum L.), tobacco (Nicotianatabacum L.) and pepper (Capsicum annuum L.). PVY symptoms vary from barely visible mosaic patterns to an extreme necrosis and premature death of plants (Tabassum et al., 2016). $P V Y$ infection is difficult to control because it is vegetatively propagated, making primary viral infection more destructive and consistent generations after generations (Gargouri-Bouzid et al., 2005). In Pakistan, due to early infection of $P V Y$ loss is about $70 \%$ (Abbas et al., 2017). Among the crucial genes of $P V Y$, capsid protein (CP) gene is involved in the encapsulation, in replication of the viral genome, movement across host cells, and transfer from infected to uninfected plants using mobile biological vectors (Callaway et al., 2001).

Several approaches have been tested to date to produce high yielding commercial varieties with advance levels of resistance, including genetic amendments of the PVY coat protein (CP) gene or P1 gene (Gargouri-Bouzid et al., 2005; Mäki-Valkama et al., 2000). Resistance exhibited by gene silencing is more effective as compared to protein mediated resistance (Mäki-Valkama et al., 2007).

In Pakistan, commercially offered high yielding potato lines fail to show resistance against viruses, especially the potato virus Y. In the current study, we aimed to find out the effect of mannose-binding lectin from the bulbs of $C$. vernus activity against the $P V Y$ coat protein gene.

\section{Materials and methods}

\section{Sequence retrieval and modeling of $C P$ protein}

The full-length amino acid sequence of potato virus $\mathrm{Y}$, coat protein (Accession \# ABK13679.1) was retrieved from the NCBI database and functional domains of Coat Protein (CP) were determined using an online InterPro server (www.ebi.ac.uk/interpro/).

Crocus vernus lectin (CVL) molecular structure, coordinate information (PDB ID: 3MEZ) was downloaded from the protein database (http://www.rcsb.org/structure/3MEZ) and the CP structure was generated using the online tool (http://zhanglab.ccmb.med.umich.edu/I-TASSER/). The validity of the predicted model was checked by calculating the Ramachandran plot which was produced by online tool RAMPAGE (http://mordred.bioc.cam.ac.uk/ rapper/rampage.php).

\section{Refinement, evaluation, and validation of CP protein model}

Using the ModRefiner online tool (https://zhanglab.ccmb.med.umich.edu/ModRefiner/), the CP model was further refined. Using Ramachandran plot and by determining the physiochemical properties of the CP protein through ProtScale, the model was evaluated and authenticated.

\section{Protein-protein docking analysis of CP and CVL}

Online server Z-DOCK (http:// zdock.umassmed.edu/) was used for docking of receptor model to fusion protein and ten coordinate files were obtained. PDBePISA 
online tool (http://www.ebi.ac.uk/pdbe/pisa/) was used to find the interactions between the CP and CVL. For the visualization of structures showing the interactions between the two proteins the PDB viewer was used.

\section{Protein source, extraction and fractionation of extract}

Crocus vernus (L.) Hill corms were kindly provided by Dr. Ahmed Akrem (Institute of Pure and Applied Biology, Bahauddin Zakariya University, Multan-Pakistan). Briefly, $10 \mathrm{~g}$ of corms were reduced to powder and homogenized in $0.1 \mathrm{M}$ phosphate buffer ( $\mathrm{pH}$ 6.5). The slurry was stirred continuously at $4{ }^{\circ} \mathrm{C}$ for $2 \mathrm{~h}$. Further, the suspension was filtered through the muslin cloth and centrifuged at $15000 \times \mathrm{g}$ for $15 \mathrm{~min}$ at $4{ }^{\circ} \mathrm{C}$. Supernatant was collected and subjected to $60 \%$ ammonium sulfate precipitation. The pellet was re-suspended in $20 \mathrm{mM}$ phosphate buffer $(\mathrm{pH} \mathrm{6.5)}$ and dialyzed overnight by dialyzing tube (Spectra/Por RC Biotech membrane, 6-8 kDa MWCO) against $10 \mathrm{mM}$ phosphate buffer (pH 6.5).

Crude protein extracts were fractionated through cation exchange chromatography where desalted protein was subjected to Hi Trap SP FF column (GE Healthcare). The column was equilibrated with $5 \mathrm{cv}$ of $50 \mathrm{mM}$ of phosphate buffer $(\mathrm{pH} 6.5)$ and then partially purified protein was loaded onto the column. Protein was eluted with $0.5 \mathrm{M}$ $\mathrm{NaCl}$ gradient and different fractions were obtained which were analyzed by SDSPAGE. The protein was quantified through the Bradford method (Bradford, 1976).

\section{Construction of pCP-PVY clone}

Full length coat protein $(\mathrm{CP})$ gene of potato virus $\mathrm{Y}(P V Y)$ was amplified from $P V Y$ infected potato samples. A fragment of full-length CP gene 807 bp was amplified with specific forward 5'-ATGGCAAATGACACAATCGAT-3' and reverse primer 5'ATCACCCTGCCACCTCTATC-3' and the deduced sequence was submitted in NCBI database under accession \# MK130988. For directional cloning in pCDNA3.1 (+) (mammalian expression vector), the amplified fragments were generated with HindIII and EcoRI restriction sites at 5 and 3 ends. The recombinant vector was named as pCPPVY.

\section{Cell line}

The HepG2 cell line was grown and maintained in Dulbecco's modified Eagle medium (DMEM) containing $100 \mathrm{U} / \mathrm{ml}$ penicillin, $100 \mu \mathrm{g} / \mathrm{ml}$ streptomycin and $10 \%$ Fetal Bovine Serum (FBS) at $37^{\circ} \mathrm{C}$ in $5 \% \mathrm{CO} 2$ atmosphere at $37^{\circ} \mathrm{C}$.

\section{Cytotoxicity assay for CVL}

Cell survival and proliferation was quantified by using the MTT assay kit (Millipore, USA). Using the HepG2 cell model, Cell viability and proliferation was evaluated. HepG2 cells were cultured in 96 well plate containing DMEM supplemented with $10 \%$ FBS, $100 \mu \mathrm{g} / \mathrm{ml}$ streptomycin and $100 \mathrm{IU} / \mathrm{ml}$ penicillin. CVL protein was diluted in different concentration ranges (110 to $770 \mu \mathrm{g} / \mathrm{ml}, 3$ wells per concentration) in 96-well plates and incubated at $37^{\circ} \mathrm{C}$ in the humidified $\mathrm{CO}_{2}$ incubator.

After incubation, the concentration range of CVL drawn from 110 to $770 \mu \mathrm{g} / \mathrm{ml}$ and were added to the wells of the plate in triplicates and the plate was again incubated at $37{ }^{\circ} \mathrm{C}$ for $24 \mathrm{~h}$ in $\mathrm{CO}_{2}$ incubator. After incubation, the exhausted media was discarded 
and fresh media along with MTT reagent $(5 \mathrm{mg} / \mathrm{ml}$ in PBS) were added to each well according to the manufacturer's instructions. The plate was then incubated at $37^{\circ} \mathrm{C}$ in a $\mathrm{CO}_{2}$ incubator for $4 \mathrm{~h}$. To dissolve the formazen crystals produced after incubation, DMSO was added in the wells. To quantify the MTT formazen product, the optical density of contents of plate was analyzed through ELISA plate reader as per described protocol.

Cell viability was attained by means of following formula (Rehman et al., 2011):

Percent cell viability $=($ Test $570 \mathrm{~nm}-620 \mathrm{~nm} /$ Control $570 \mathrm{~nm}-620 \mathrm{~nm}) \times 100$.

\section{Hemagglutinating activity}

The hemagglutinating activity of the CVL was evaluated against the rabbit erythrocytes using the U-shaped bottom 96 wells microtiter plate as described by Ynalvez et al. (2015). Briefly, twofold serial dilutions of the CVL were made in phosphate buffer saline (PBS) and was incubated with $2 \%$ erythrocytes suspension in equal volume and kept at room temperature for $1 \mathrm{~h}$, while control contains the PBS in spite of the CVL. Positive results indicated the red-carpet layer while negative results show the red button formation in the well.

\section{Co-transfection}

The HepG2 cells were cultured at a cell density of $1 \times 10^{6}$ cells per well in a 6-well plate. CVL protein extract and pCP-PVY plasmid DNA were co-transfected at 50-70\% cell confluence. Lipofectamine 2000 (Invitrogen, CA) was used as transfection reagent. For the down regulation of CP-PVY mRNA, $50 \mathrm{ng}-1 \mu \mathrm{g}$ construct DNA was used along with three different CVL concentrations; 30, 60 and $90 \mu \mathrm{g} / \mathrm{ml}$. Experiments were carried out in triplicate.

\section{Real-time PCR analysis}

To measure the anti-PVY potential of CVL, the mRNA expression of CP gene was revealed through real time PCR assay. Post co-transfection, total RNA was isolated from HepG2 cells by using TRIzol reagent (Invitrogen) and $1 \mu \mathrm{g}$ was used to synthesize complementary DNA (cDNA) by using the cDNA synthesis kit (Thermo Scientific, Lithuania). Specific forward 5'-TGTGGGTTTAGCGCGTTATG-3' and reverse 5'GTGCCTCTCTGTGTTCTCCT -3' were used to amplify $172 \mathrm{bp}$ amplicon. The assay was run in triplicate in the PikoReal ${ }^{\mathrm{TM}}$ Real-Time PCR system (Thermo Scientific). Reactions were prepared in a total volume of $10 \mu \mathrm{l}$ containing: $1 \mu \mathrm{l}$ cDNA, $0.5 \mu \mathrm{l}$ of each 10 pmoles primer, $5 \mu$ of Maxima SYBR Green qPCR Master Mix (2X) (Thermo scientific) and $2.5 \mu \mathrm{RNase/DNase-free} \mathrm{sterile} \mathrm{water.} \mathrm{The} \mathrm{cycle} \mathrm{profile} \mathrm{comprised} \mathrm{of} 30$ cycles with denaturation at $94{ }^{\circ} \mathrm{C}$ for $30 \mathrm{~s}$, annealing at $54{ }^{\circ} \mathrm{C}$ for $30 \mathrm{~s}$ and extension at $72{ }^{\circ} \mathrm{C}$ for $30 \mathrm{~s}$ after an initial denaturation at $94{ }^{\circ} \mathrm{C}$ for $10 \mathrm{~min}$. For normalization, $\beta$-actin was used as a control. The relative gene expression analysis was measured by using $\mathrm{Cq}$ values in different samples. Each real-time PCR assay was performed in triplicate.

\section{Statistical analysis}

Statistical analysis was carried out using GraphPad Prism 7. Triplicate studies were performed. Descriptive statistics were used to evaluate the mean and standard deviation 
of the results. One-way ANOVA was used was to investigate a significant reduction in the cell viability and MRNA expression of the CP gene at $P \leq 0.05$.

\section{Results}

In silico modeling, refinement, evaluation, and validation of $\mathrm{CP}$ gene was performed with online available tools as indicated in Figure $1 A$ and $B$. The verified in silico model of CP was used for docking analysis.

IPR001592 Potyvirus coat protein

\section{Other features}

$\mathbf{A}$

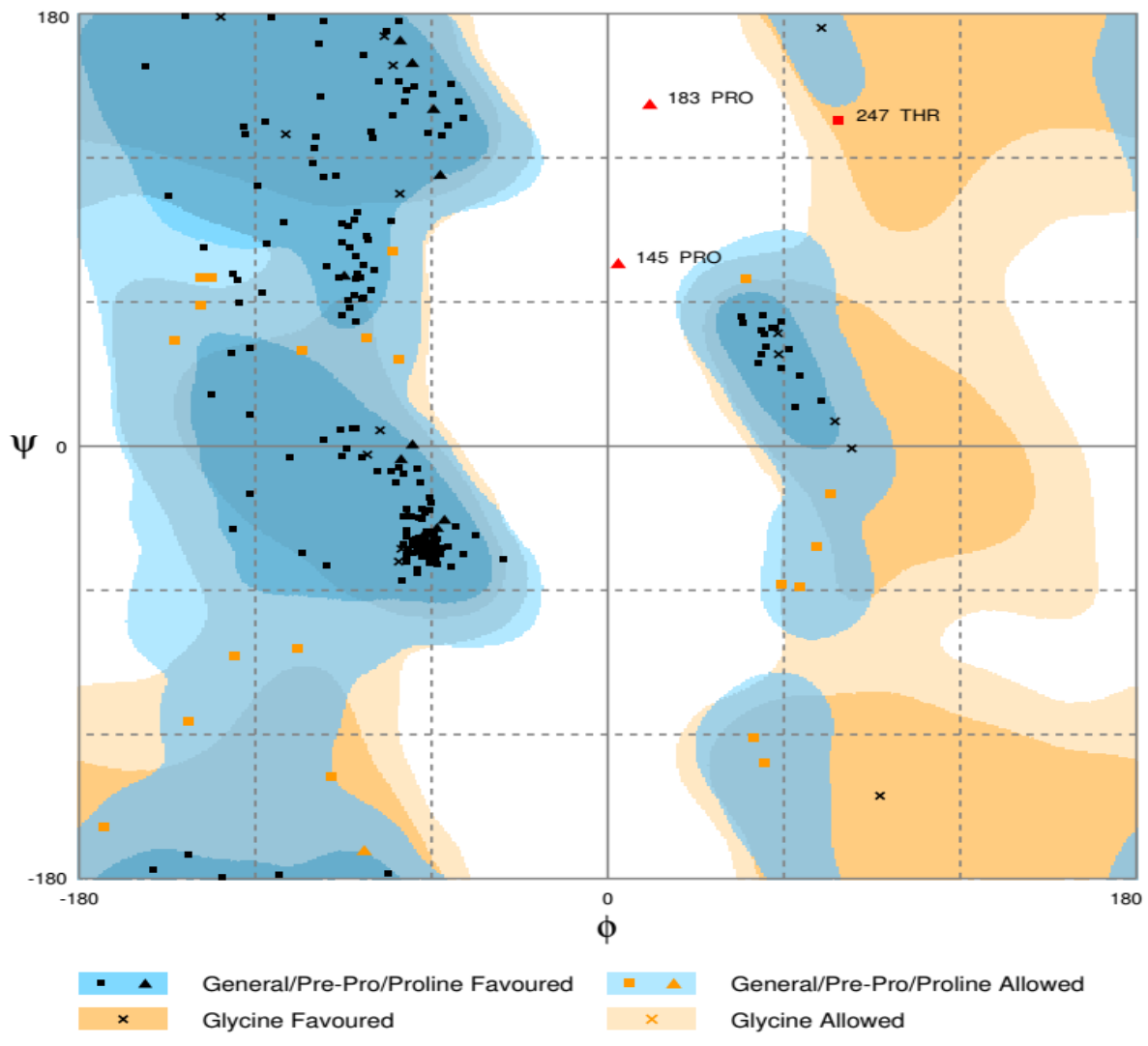

B

Figure 1. A Functional domains analysis of CP sequence through InterPro is showing Potyvirus CP domain. B Ramachandran plot analysis of Capsid protein model to visualize dihedral angles; $\phi$ against $\psi$. Only two residues indicated with a red triangle in the figure are in the outlier region except these two, all other residues are in favored and allowed regions

Primary structure examination of the $\mathrm{CP}$ model was executed utilizing Protparam (https://web.expasy.org/protparam/). It was found that the CP has an aggregate length of 267 amino acids and hypothetical $p I$ of 6.61 . The instability index was 43.03 , ordering it 
as not steady protein. The evaluated half-life in mammalian reticulocytes was $30 \mathrm{~h}$, whereas in yeast and Escherichia coli is over twenty and $10 \mathrm{~h}$, on an individual basis (Fig. 2A). Similarly, the CVL protein model was taken as a PDB format from the online protein data bank. CVL protein contains four chains in which chain 1 and 3 were the same and chain 2 and 4 were same as given with the amino acid details (Fig. 2B).
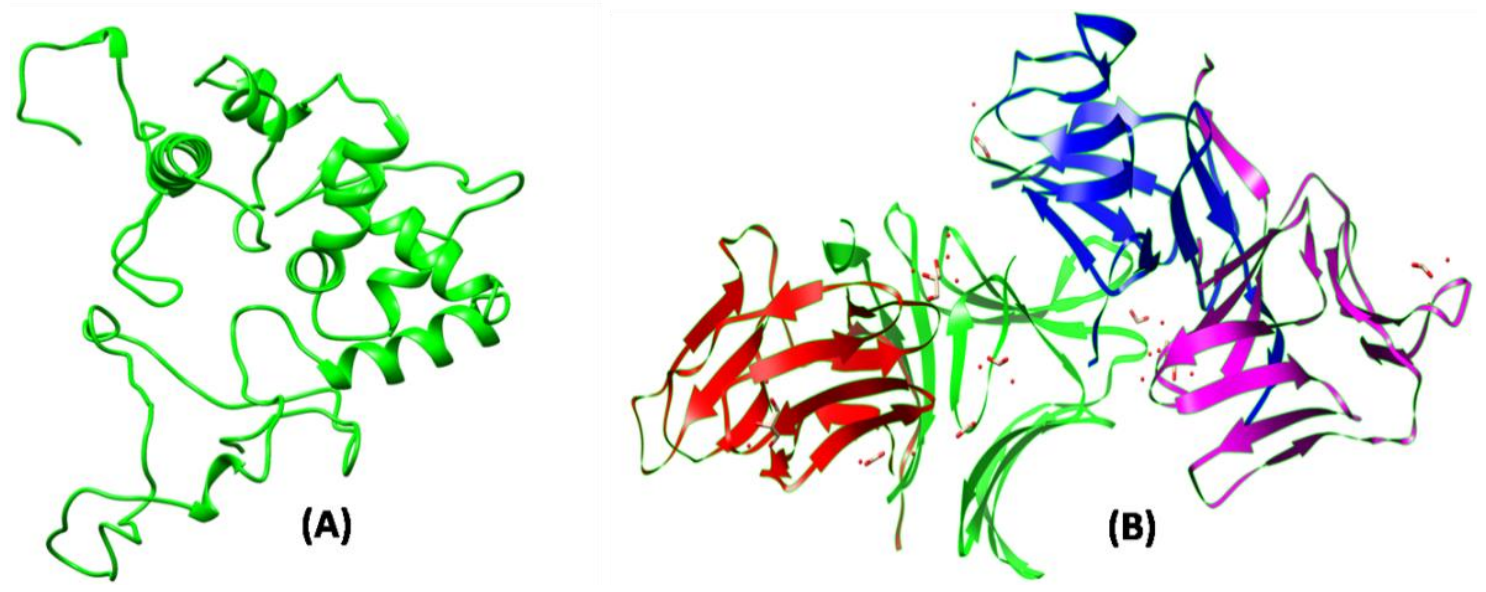

Figure 2. Three-dimensional protein models of $(\boldsymbol{A}) P V Y$ coat protein and $(\boldsymbol{B}) C V L$ protein, predicted by I-TASSER. In $(B)$, the red color chains present A chain, green shows $B$, magenta $C$ and blue presenting $D$ chain

\section{Docking analysis of coat protein with CVL}

The amino acids and molecules concerned in interchain $\mathrm{H}$ bonds, while not choosing any residue within the $\mathrm{CP}$, were assessed utilizing the ZDOCK server. The interactions created through the ZDOCK server between CP and CVL protein are shown by the hydrogen bonds between the two proteins. Details of hydrogen bonds are given as in Tables 1 and 2.

Table 1. Hydrogen bonds between CP and CVL (A and C domain) obtained from PDBePisa. Interactions with a value less than 3.0 were considered to have highlighted bond distances

\begin{tabular}{|c|c|c|c|}
\hline Sr. No. & $\mathbf{C P}$ & Dist. [Å] & CVL \\
\hline 1 & :GLY 131 [N] & 3.16 & A: Tyr $76[\mathrm{OH}]$ \\
\hline 2 & :Asn 130 [N] & 2.94 & A: Tyr $76[\mathrm{OH}]$ \\
\hline 3 & :Tyr $185[\mathrm{OH}]$ & 3.09 & A: Ser $79[O]$ \\
\hline 4 & :Tyr $181[\mathrm{OH}]$ & 2.73 & A: Val $97[O]$ \\
\hline 5 & :Arg 184 [NH1] & 3.83 & A: Val $97[O]$ \\
\hline 6 & :Tyr 181 [N] & 3.79 & A: Tyr $100[\mathrm{OH}]$ \\
\hline 7 & :Arg 189 [N] & 3.03 & A: Gly 101 [O] \\
\hline 8 & :Tyr $181[\mathrm{OH}]$ & 3.47 & A: Val $97[\mathrm{~N}]$ \\
\hline 9 & :Leu 187 [O] & 3.11 & A: Gly $101[\mathrm{~N}]$ \\
\hline 10 & :Ile 188 [O] & 3.00 & A: Tyr $87[\mathrm{OH}]$ \\
\hline 11 & :Ala 224 [O] & 3.20 & A: Asn 81 [ND2] \\
\hline 12 & :Ala 225 [O] & 2.94 & A: Asn 81 [ND2] \\
\hline 13 & :Asp 254 [OD2] & 2.56 & A: Arg 84 [NH2] \\
\hline
\end{tabular}


Table 2. Hydrogen bonds between CP and CVL ( $B$ and D domain) obtained from PDBePisa. Highlighted bond distances were considered as an interaction whose value was less than 3.0

\begin{tabular}{|c|c|c|c|}
\hline Sr. No. & $\mathbf{C P}$ & Dist. [Å] & CVL \\
\hline 1 & :Lys 177 [NZ] & 3.76 & B: Asn $1[\mathrm{O}]$ \\
\hline 2 & :Lys 147 [NZ] & 3.16 & B: Asp 17 [OD2] \\
\hline 3 & :Tyr $144[\mathrm{OH}]$ & 2.58 & B: Gln 57 [O] \\
\hline 4 & :Val 134 [O] & 3.84 & B: Asn 1 [ND2] \\
\hline 5 & :Tyr $181[\mathrm{OH}]$ & 3.17 & B: $\operatorname{Arg} 4[\mathrm{~N}]$ \\
\hline 6 & :Gly 138 [O] & 3.71 & B: Ser 12 [OG] \\
\hline 7 & :Gly 138 [O] & 3.61 & B: Arg 62 [NH2] \\
\hline 8 & :Glu 140 [[OE1] & 3.72 & B: Thr 72 [OG1] \\
\hline 9 & :Asp 103 [OD1] & 3.86 & B: Leu $76[\mathrm{~N}]$ \\
\hline
\end{tabular}

The two proteins interacted only through hydrogen bonds and no disulphide or covalent bonds were observed. The PDBePISA tool was utilized to locate the most effective interaction between coat protein and the two chains, i.e. chain A and B of CVL as mentioned before as CVL has four chains and chain 1 and 3 are same as chain 2 and 4. The outcomes demonstrated that various residues of the $\mathrm{CP}$ are predictable to act with the chain of CVL. In the case of A and C domain of CVL interaction with CP, totally 13 hydrogen bonds were observed from which three bonds, which are highlighted in Table 1 has been shown in Figure 3A. In the case of B and D domain of CVL interacting with $\mathrm{CP}$, totally 9 hydrogen bonds were observed from which two bonds, which are highlighted in Table 2 has been shown in Figure $3 B$.

\section{CVL protein purification and cytotoxic activity}

CVL protein was purified through cation exchange chromatography using the column Hi Trap SP FF (GE Healthcare). On SDS-PAGE, two final fractions were obtained with their exchange profiles; one was of $10.5 \mathrm{kDa}$ and the other fraction was about $11.5 \mathrm{kDa}$ (Fig. $4 A$ and $B$ ).

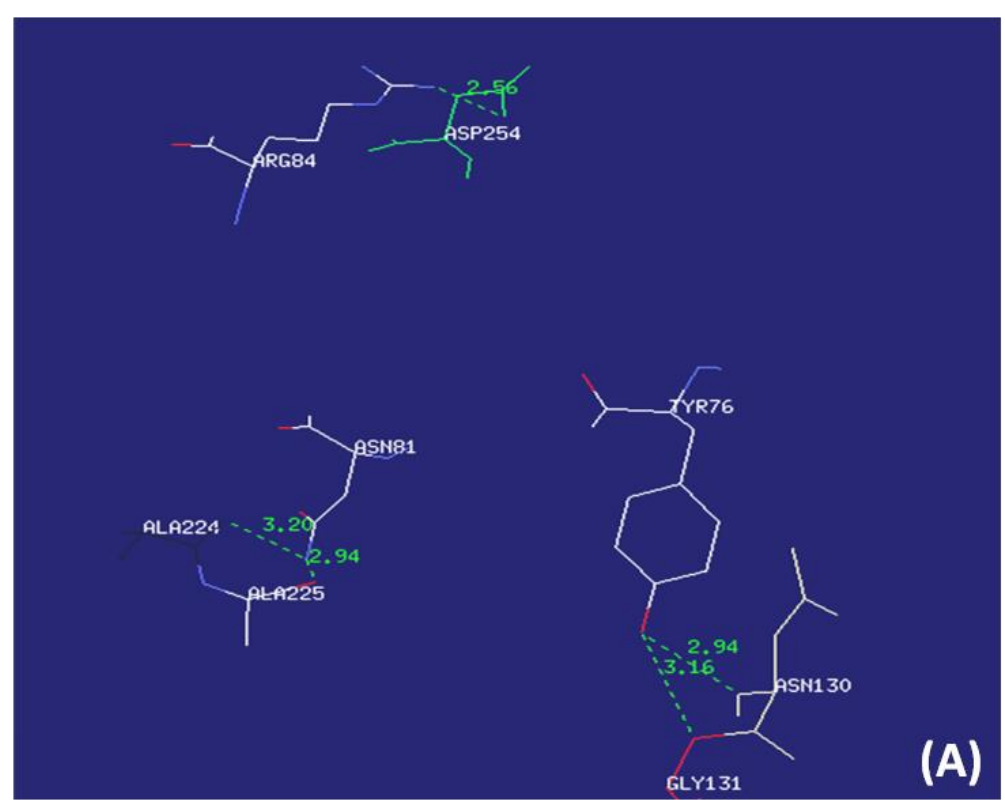




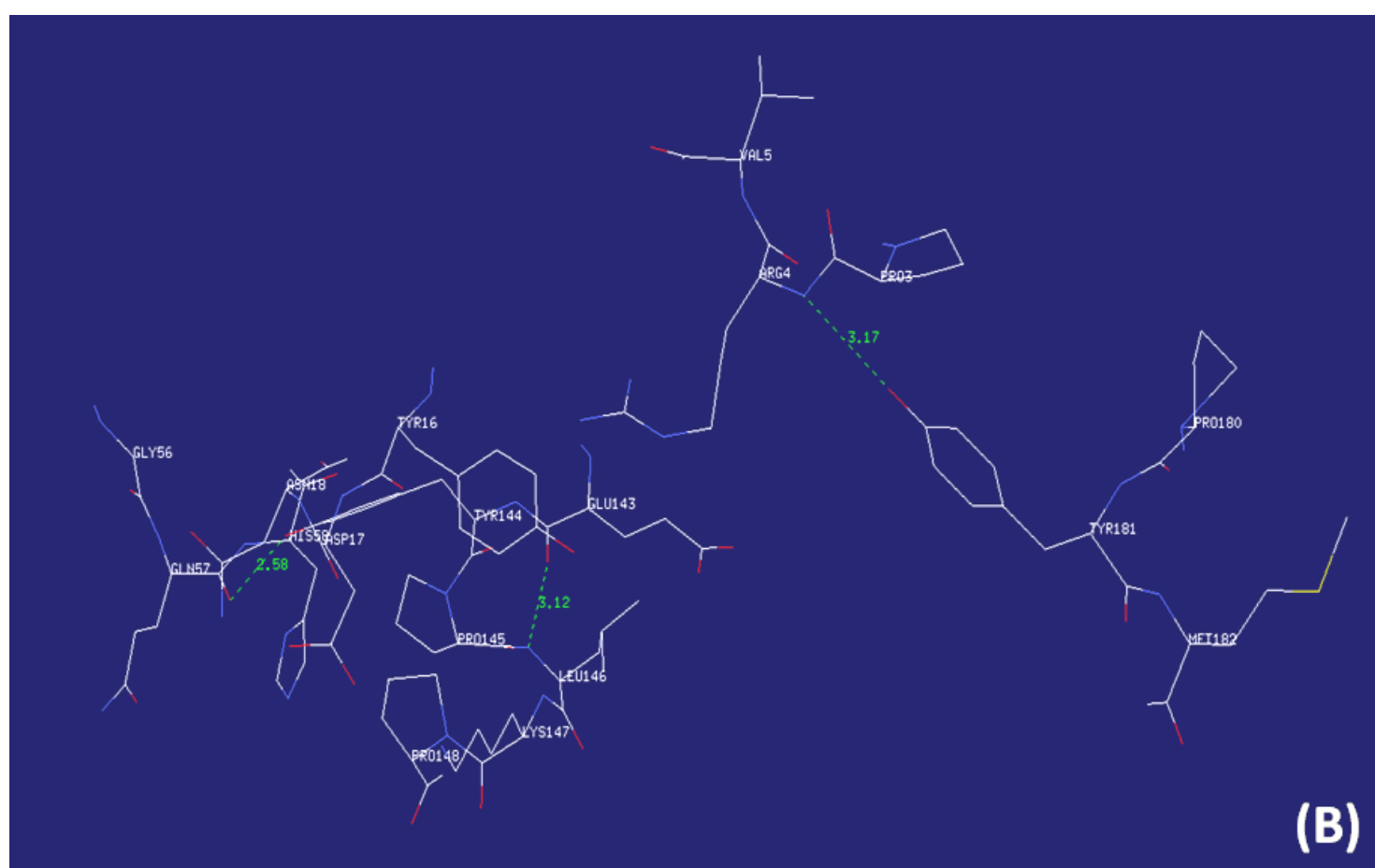

Figure 3. In-silico protein-protein docking analysis. A Interactions of CVL A and C chains with $C P$ visualized by PDBViewer. Asn 130, Ala 225 and Asp 254 residues of CP were interacting with Tyr 76, Asn 81 and Arg84 residues of CVL. $B$ Interactions of $B$ and D chains of CVL with $C P$ visualized by PDBViewer. Lys 147, Tyr 144 and Tyr 181 residues of CP were interacting with Asp 17, Gln 57 and Arg 4 residues of CVL

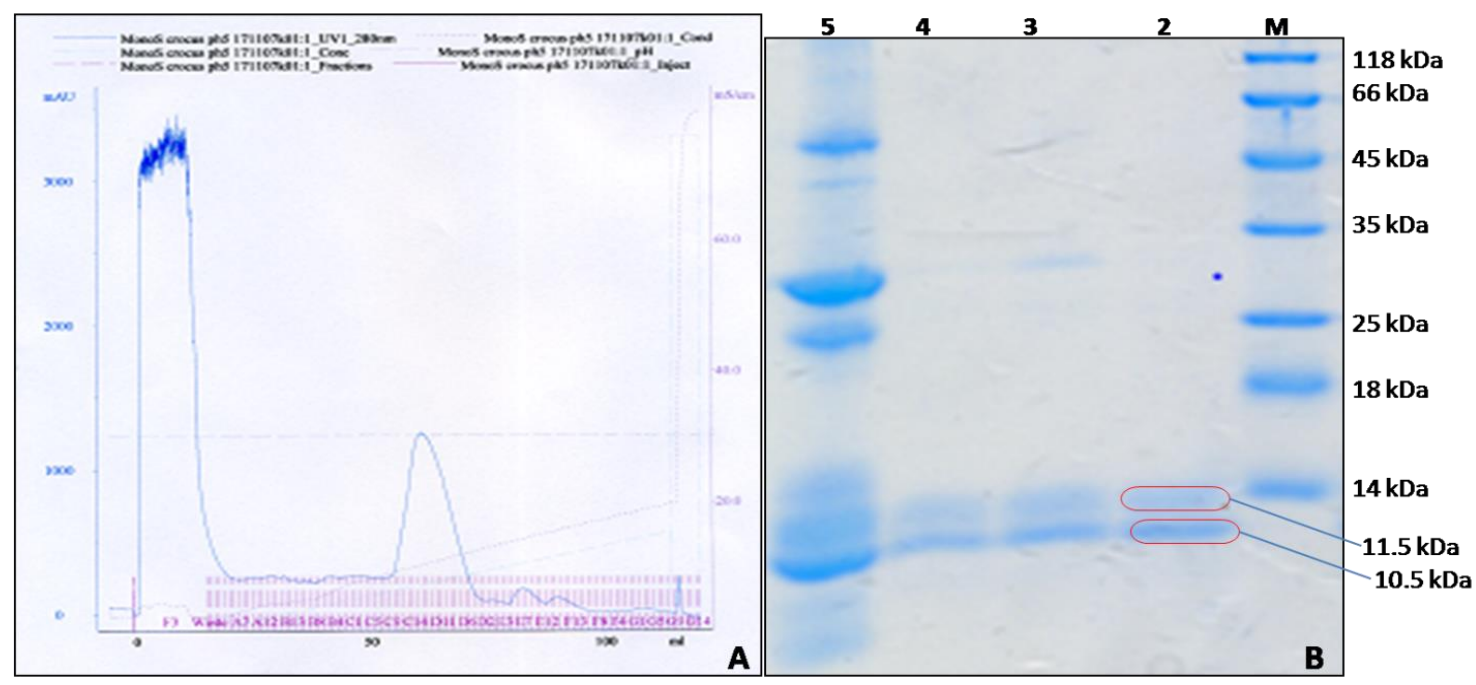

Figure 4. SDS PAGE shows purified fractions of the CVL. Lane 1: PageRuler ${ }^{\mathrm{TM}}$ unstained Protein Ladder (Catalog number: 26610); lane 2, 3 and 4: purified CVL fractions obtained after cation exchange chromatography; lane 5: crude CVL protein after desalting

The cytotoxic concentration that inhibited $50 \%$ of cell growth (CC50) showed that the CVL protein extract had the highest cytotoxicity with CC50 value of $770 \mu \mathrm{g} / \mathrm{ml}$ (Fig. 4). It was found that at $110 \mu \mathrm{g} / \mathrm{ml} \mathrm{CVL}$ concentration, the cytotoxicity was 
$111.47 \%$. Similarly, at 220, 330, 440, 550, $660 \mu \mathrm{g} / \mathrm{ml} \mathrm{CVL}$ concentrations, the cytotoxicity was recorded as $71.87,62.39,65.13$ and $54.00 \%$ as compared to the control (Fig. 5).

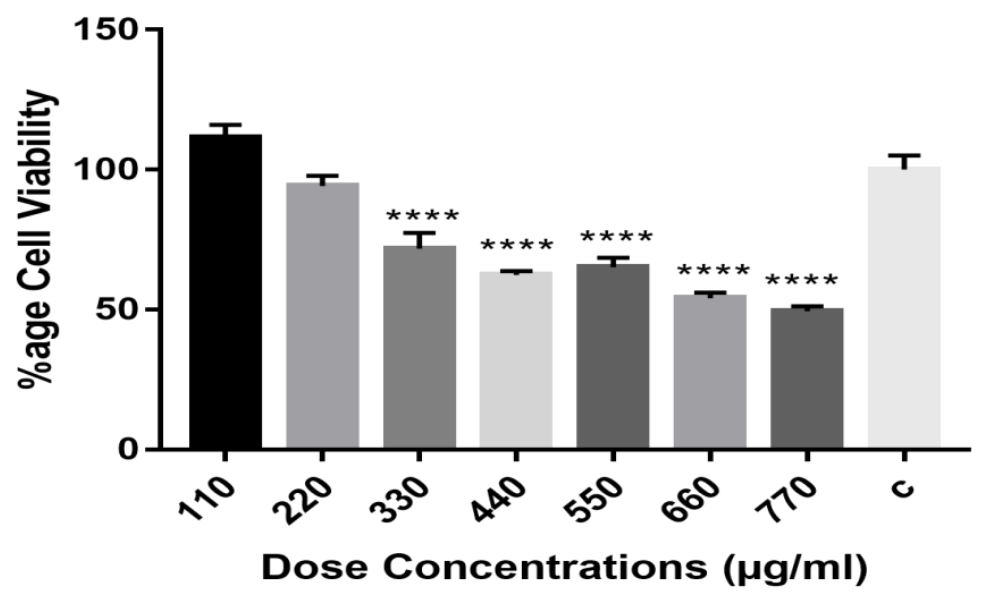

Figure 5. Cytotoxicity of CVL to reveal a safe dose limit. The dose concentration of CVL purified protein extracts was ranging between $110-770 \mu \mathrm{g} / \mathrm{ml}$. Percentage cell survivals were calculated for each dose. Bars indicate the standard deviation. One-way ANOVA (see tables in the Appendix) shows the significant reduction of cell viability at the concentrations 330, 440, 550, 660 and $770 \mu \mathrm{g} / \mathrm{ml} \mathrm{at} P<0.0001$. Three biological replicated were processed to obtain data

\section{Hemagglutination activity}

The minimum concentration of purified CVL was observed at the end of the 1-h incubation period, which shows hemagglutination activity against the rabbit erythrocytes was high approximately $100 \mu \mathrm{g} / \mathrm{ml}$ as described by Van Dam et al. (2000).

\section{Antiviral activity of CVL purified fractions against CP-PVY}

In the antiviral screening assay, the CVL purified fractions were found to be active against the CP-PVY in in-vitro assays. Briefly, $30 \mu \mathrm{g} / \mathrm{ml} \mathrm{CVL}$ displayed $98 \%$ inhibition of CP-PVY, $99 \%$ inhibition at $60 \mu \mathrm{g} / \mathrm{ml}$, while up to $100 \%$ inhibition at $90 \mu \mathrm{g} / \mathrm{ml} \mathrm{CVL}$ concentration (Fig. 6). However, the control sample did not exhibit any inhibition of CP-PVY expression.

\section{Discussion}

Potato is central crop and it is rigorously affected by Potato Virus $\mathrm{Y}(P V Y)$. The essential point of the present work was to utilize CVL to effectively build firm PVYresistance in in-vitro assays. Lectins derived from different plants have shown the antiviral activity against different plant viruses (Lusvarghi and Bewley, 2016; Liu et al., 2014). CVL is a tetrameric protein comprising of four subunits with two chains of $10.5 \mathrm{kDa}$, while other two of $11.5 \mathrm{kDa}$ and is capable of agglutinating the rabbit erythrocytes. Previous studies have shown that CVL and lectin from $C$. sativus has identical N-terminal sequences and moreover, CVL showed reasonable similarity with respect to the two domain lectins of tulip and Arum maculatum, which reinforce that the 
CVL belongs to monocot mannose-binding lectins (Van Dam et al., 2000). There are numbers of pathogens, including bacteria, fungi, viruses and parasites through, which mannose binding lectins interact and provide protection against these to the host (Kilpatrick, 2002).

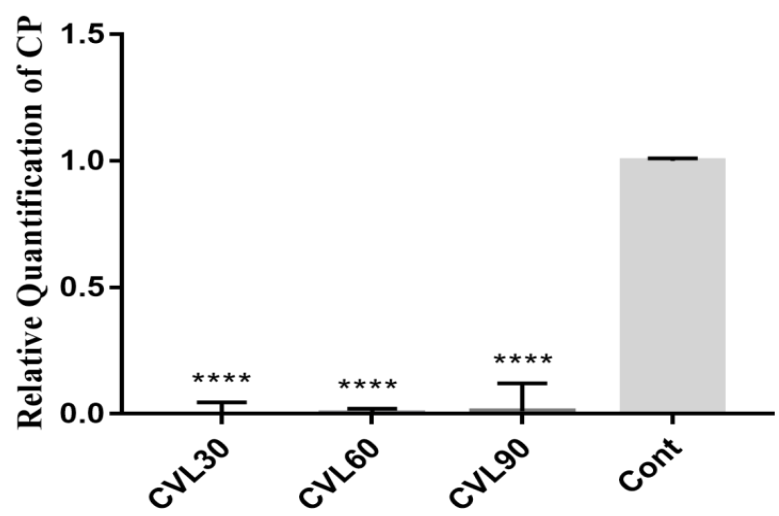

Dose Concentrations $(\mu \mathrm{g} / \mathrm{ml})$

Figure 6. Real time PCR study of down regulation of CP-PVY against CVL. Antiviral activity of $C V L$ dose against CP-PVY. Three dose concentrations of CVL were tested; 30, 60 and $90 \mu \mathrm{g} / \mathrm{ml}$. Percent inhibition of CP-PVY mRNA was measured, bars in the graph depict the standard deviation, while a significant decrease in CP gene expression was observed in 30, 60 and $90 \mu \mathrm{g} / \mathrm{ml}$ at $P<0.0001$

Protein docking refers to the scheming of three-dimensional (3D) structure of a protein initiating with the separate structures of protein subunits. The aim of protein docking is to know how proteins interact (Vitkup et al., 2001). Aloy and Russell stated that an estimate of 9 interaction partners are present for each protein and these interactions are one of around 10000 basic types, out of which only 2000 are known till date (Aloy and Russell, 2004) protein docking has emerged as a distinct computational field which make use of techniques and knowledge from diverse spectrum of science with the intention of formulating in silico how macromolecules like proteins act (Camacho et al., 2000). The in-silico protein-protein interaction showed that CP interact with the chain $\mathrm{C}$ and chain $\mathrm{B}$ of CVL. Our findings correlate with of Zhang et al. (2017b) who reported that Arg90 of TMV (tobacco mosaic virus) has a major role of interaction with the antiviral enantiomerica-aminophosphonate derivatives for the loss of virus ability to cause infection. In a similar study, mannose binding lectin from Lycorisradiate indicated that Gln80, Asp82, Asn84 and Tyr88 are the main residues which are involved in the interaction with mannose (Zhu et al., 2013).

We adopted in-vitro assay to reveal the antiviral effect of CVL, which is based on transient expression of the CP gene in the mammalian cell line. Several reports support the adoption of in-vitro assay to screen potential plant extracts against plant viruses like Li et al. (2012) showed that tobacco mosaic virus (TMV) virions were transfected into HeLa cells to generate the expression of the CP gene of $T M V$. The possibility of plant capsid uptake and release in mammalian cells has been proposed in case of clover necrotic mosaic virus ( $R C N M V$ ) by Lockney et al. (2011). In another study, 480 bp of $\mathrm{CP}$ from $P V Y$ was transfected into $\mathrm{CHO}$ cells and its mRNA knockdown assay was conducted with siRNA (Tabassum et al., 2011). Furthermore, plant viral capsids have 
been used as vectors in mammalian cells for gene delivery and expression studies (Azizgolshani et al., 2013). More recently, Arabidopsis cryptochrome was successfully expressed in the HEK293T cells to produce a photochemically active product (Yang et al., 2016).

To reveal the activity of lectin (CVL), instead of full $P V Y$ virus particles, we cloned the $\mathrm{CP}$ gene as it is involved in the number of virus infection events like, uncoating and translation of the viral RNA, targeting the site of replication and in the transmission of potyviruses by vectors/aphids (Bol, 2008). There are some studies which clearly indicate involvement of $\mathrm{CP}$ transgene in creating resistance in transgenic potato crops (Bukovinszki et al., 2007; Gargouri-Bouzid et al., 2005).

The high antiviral effect of CVL protein fractions (up to $100 \%$ in our study) attributed the effectiveness of plant derived lectins in preventing notorious plant viruses like PVY. Plant lectins might show involvement in recognition of pathogenic microorganisms. Lectin from a soybean show high affinity for binding to $\beta$-glucan, which is a powerful PAMP of Phytophthorasojae (Mithöfer et al., 2000). Similarly, spread of tobacco etch virus (TEV), a single-stranded RNA plant virus belonging to the genus Potyvirus is restricted by, the Arabidopsis thaliana restricted TEV movement 1 (RTM1) lectin gene (Whitham et al., 2000). Moreover, a jacalin-type lectin gene exhibits resistance to potexviruses which belong to family Potexviridae. This resistance is conferred in the early stage of infection caused by plant viruses as compared to another lectinRTM1 which shows resistance at an advanced stage of viral infection, implementing the vital role of lectin-mediated resistance in a multiplicity of plant-virus relation (Yamaji et al., 2012). Conclusively, we have reported the antiviral activity of lectin derived from $C$. vernus against potato virus $\mathrm{Y}$. The purified fractions of CVL exhibited the strong antiviral effect against $P V Y$. To the best of our knowledge, this is the first report on the antiviral activity of CVL against $P V Y$. Furthermore, as results showing the maximum down regulation of the CP gene due to CVL, which clearly indicate that efficiency of the CVL against PVY. The genetic integration of lectin in the potato genome could provide complete protection from PVY in transgenic potato plants.

\section{Conclusion}

Lectins obtained from different plants have been shown to have antiviral activity against various plant viruses. The purified Crocus vernus lectin exhibited the strong antiviral effect against $P V Y$. This is the first study of CVL's antiviral activity against PVY, as far as we know. Genetic incorporation of lectin into the genome of potatoes could provide comprehensive defense against PVY in transgenic potato plants.

Conflict of interests. The authors have no conflict of interests.

\section{REFERENCES}

[1] Abbas, A., Amrao, L. (2017): Potato virus Y: an evolving pathogen of potato worldwide. - Pakistan Journal of Phytopathology 29: 187-191.

[2] Aloy, P., Russell, R. B. (2004): Ten thousand interactions for the molecular biologist. Nature biotechnology 22: 1317. 
[3] Azizgolshani, O., Garmann, R. F., Cadena-Nava, R., Knobler, C. M., Gelbart, W. M. (2013): Reconstituted plant viral capsids can release genes to mammalian cells. Virology 441: 12-17.

[4] Balzarini, J. (2007): Targeting the glycans of glycoproteins: a novel paradigm for antiviral therapy. - Nature Reviews Microbiology 5: 583.

[5] Bol, J. F. (2008): Role of Capsid Proteins. - In: Uyeda, I., Masuta C. (eds.) Plant Virology Protocols. Humana Press, Totowa, NJ, pp. 21-31.

[6] Bradford, M. M. (1976): A rapid and sensitive method for the quantitation of microgram quantities of protein utilizing the principle of protein-dye binding. - Analytical Biochemistry 72: 248-254.

[7] Bukovinszki, Á., Divéki, Z., Csányi, M., Palkovics, L., Balázs, E. (2007): Engineering resistance to PVY in different potato cultivars in a marker-free transformation system using a 'shooter mutant' A. tumefaciens. - Plant Cell Reports 26: 459-465.

[8] Callaway, A., Giesman-Cookmeyer, D., Gillock, E. T., Sit, T. L., Lommel, S. A. (2001): The multifunctional capsid proteins of plant RNA viruses. - Annual Review of Phytopathology 39: 419-460.

[9] Camacho, C. J., Gatchell, D. W., Kimura, S. R., Vajda, S. (2000): Scoring docked conformations generated by rigid-body protein-protein docking. - Proteins: Structure, Function, and Bioinformatics 40: 525-537.

[10] Davidson, E., Forrest, J. M. S., Morrison, I. M., Stewart, D. (1999): Mannose-specific plant lectins from plants as diagnostics, vaccines and tools for the elucidation of viral infection mechanisms in animals. - Annual Report for the Scottish Crop Research Institute for 2000, pp. 125-128.

[11] Gargouri-Bouzid, R., Jaoua, L., Mansour, R. B., Yemna, H., Malika, A., Radhouane, E. (2005): PVY resistant transgenic potato plants (cv Claustar) expressing the viral coat protein. - Journal of Plant Biotechnology 7: 1-6.

[12] Golotin, V. A., Filshtein, A. P., Chikalovets, I. V., Kim, N. Y., Molchanova, V. I., Chernikov, O. V. (2019): Expression and purification of a new lectin from mussel Mytilus trossulus. - Protein Expression and Purification 154: 62-65.

[13] Kilpatrick, D. C. (2002): Mannan-binding lectin: clinical significance and applications. Biochimica et Biophysica Acta (BBA)-General Subjects 1572: 401-413.

[14] Kitajima, E. W., De Ávila, A. C., Resende, R. O. (1997): Taxonomia de vírus de plantas. - Fitopatologia Brasileira 22: 5-24.

[15] Lam, Y. W., Ng, T. B. (2001): A monomeric mannose-binding lectin from inner shoots of the edible chive (Allium tuberosum). - Journal of protein chemistry 20: 361-366.

[16] Li, L. I., Wang, L., Xiao, R., Zhu, G., Li, Y., Liu, C., Yang, R., Tang, Z., Li, J., Huang, W., Chen, L. (2012): The invasion of tobacco mosaic virus RNA induces endoplasmic reticulum stress-related autophagy in HeLa cells. - Bioscience Reports 32: 171-184.

[17] Liu, X. Y., Li, H., Zhang, W. (2014): The lectin from Musa paradisiaca binds with the capsid protein of tobacco mosaic virus and prevents viral infection. - Biotechnology \& Biotechnological Equipment 28: 408-416.

[18] Lockney, D. M., Guenther, R. N., Loo, L., Overton, W., Antonelli, R., Clark, J., Hu, M., Luft, C., Lommel, S. A., Franzen, S. (2010): The Red clover necrotic mosaic virus capsid as a multifunctional cell targeting plant viral nanoparticle. - Bioconjugate Chemistry 22: $67-73$.

[19] Lusvarghi, S., Bewley, C. (2016): Griffithsin: an antiviral lectin with outstanding therapeutic potential. - Viruses 8: 296.

[20] Mäki-Valkama, T., Pehu, T., Santala, A., Valkonen, J. P., Koivu, K., Lehto, K., Pehu, E. (2000): High level of resistance to potato virus $Y$ by expressing P1 sequence in antisense orientation in transgenic potato. - Molecular Breeding 6: 95-104.

[21] Mithöfer, A., Fliegmann, J., Neuhaus-Url, G., Schwarz, H., Ebel, J. (2000): The Hepta-? Glucoside elicitor-binding proteins from legumes represent a putative receptor family. Biological Chemistry 381: 705-713. 
[22] Muslim, S. N., Al-Kadmy, I., Auda, I. G., Ali, M., Naseer, A., Al-Jubori, S. S. (2018): A novel genetic determination of a lectin gene in Iraqi Acinetobacter baumannii isolates and use of purified lectin as an antibiofilm agent. - Journal of AOAC International 101: 16231630.

[23] Rehman, S., Ashfaq, U. A., Riaz, S., Javed, T., Riazuddin, S. (2011): Antiviral activity of Acacia nilotica against Hepatitis C Virus in liver infected cells. - Virology journal 8: 220.

[24] Singh, R. S., Walia, A. K., Kennedy, J. F. (2018): Purification and characterization of a mitogenic lectin from Penicillium duclauxii. - International Journal of Biological Macromolecules 116: 426-433.

[25] Sreeramulu, B., Arumugam, G., Paulchamy, R., Karuppiah, H., Sundaram, J. (2018): $\beta$ Galactoside binding lectin from caddisfly larvae, Stenopsyche kodaikanalensis with selective modes of antibacterial activity: purification and characterization. - International Journal of Biological Macromolecules 115: 1033-1045.

[26] Tabassum, B., Nasir, I. A., Husnain, T. (2011): Potato virus Y mRNA expression knockdown mediated by siRNAs in cultured mammalian cell line. - Virologica Sinica 26: 105-113.

[27] Tabassum, B., Nasir, I. A., Khan, A., Aslam, U., Tariq, M., Shahid, N., Husnain, T. (2016): Short hairpin RNA engineering: in planta gene silencing of potato virus Y. Crop Protection 86: 1-8.

[28] Van Damme, E. J., Astoul, C. H., Barre, A., Rougé, P., Peumans, W. J. (2000): Cloning and characterization of a monocot mannose-binding lectin from Crocus vernus (family Iridaceae). - European Journal of Biochemistry 267: 5067-5077.

[29] Vitkup, D., Melamud, E., Moult, J., Sander, C. (2001): Completeness in structural genomics. - Nature Structural \& Molecular Biology 8: 559.

[30] Whitham, S. A., Anderberg, R. J., Chisholm, S. T., Carrington, J. C. (2000): Arabidopsis RTM2 gene is necessary for specific restriction of tobacco etch virus and encodes an unusual small heat shock-like protein. - The Plant Cell 12: 569-582.

[31] Yamaji, Y., Maejima, K., Komatsu, K., Shiraishi, T., Okano, Y., Himeno, M., Sugawara, K., Neriya, Y., Minato, N., Miura, C., Hashimoto. (2012): Lectin-mediated resistance impairs plant virus infection at the cellular level. - The Plant Cell 24: 778-793.

[32] Yang, L., Wang, X., Deng, W., Mo, W., Gao, J., Liu, Q., Zhang, C., Wang, Q., Lin, C., Zuo, Z. (2016): Using HEK293T expression system to study photoactive plant cryptochromes. - Frontiers in Plant Science 7: 940.

[33] Ynalvez, R. A., Cruz, C. G., Ynalvez, M. A. (2015): Isolation, partial purification and characterization of Texas live oak (Quercus fusiformis) lectin. - Advances in Bioscience and Biotechnology 6: 470.

[34] Zhang, W., van Eijk, M., Guo, H., van Dijk, A., Bleijerveld, O. B., Verheije, M. H., Wang, G., Haagsman, H. P., Veldhuizen, E. J. (2017a): Expression and characterization of recombinant chicken mannose binding lectin. - Immunobiology 222: 518-528.

[35] Zhang, W., Li, X., Zhang, G., Ding, Y., Ran, L., Luo, L., Wu, J., Hu, D., Song, B. (2017b): Binding interactions between enantiomeric $\alpha$-aminophosphonate derivatives and tobacco mosaic virus coat protein. - International Journal of Biological Macromolecules 94: 603-610.

[36] Zhu, Q. K., Zhu, M. L., Zou, J. X., Feng, P. C., Fan, G. T., Liu, Z. B., Wang, W. J. (2013): Molecular modeling and docking of mannose-binding lectin from Lycoris radiata. - Chemical Research in Chinese Universities 29: 1153-1158. 


\section{APPENDIX}

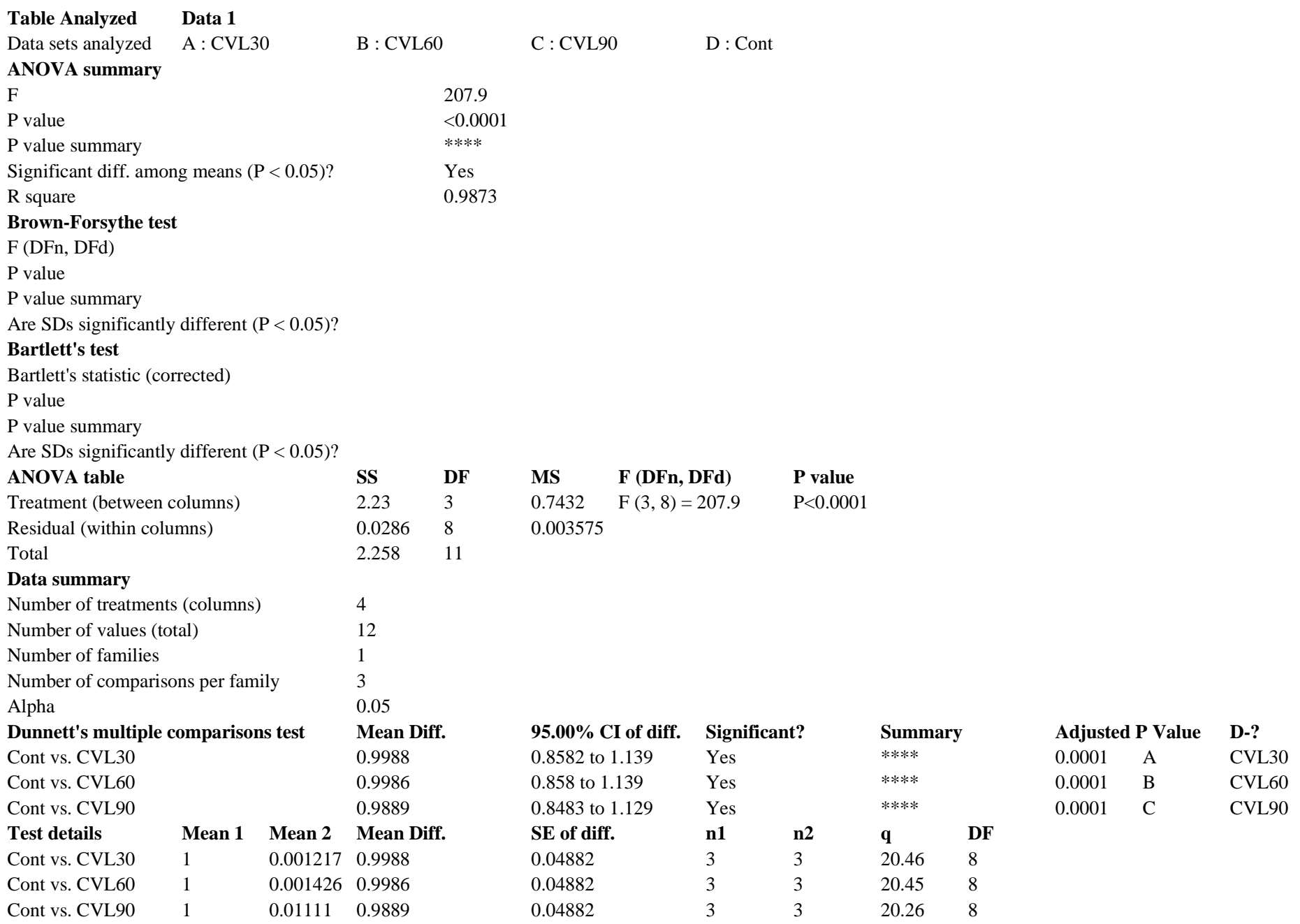


Table Analyzed

Data 1

Data sets analyzed
ANOVA summary

F

P value

P value summary

Significant diff. among means $(\mathrm{P}<0.05)$ ?

R square

Brown-Forsythe test

$\mathrm{F}$ (DFn, DFd)

P value

P value summary

Are SDs significantly different $(\mathrm{P}<0.05)$ ?

Bartlett's test

Bartlett's statistic (corrected)

$P$ value

$P$ value summary

Are SDs significantly different $(\mathrm{P}<0.05)$ ?

ANOVA table SS

SS

Residual (within columns) $\quad 221.5 \quad 16$

$\begin{array}{lll}\text { Residual (within columns) } & 221.5 & 16 \\ \text { Total } & 11247 & 23\end{array}$

Number of treatments (columns)

Number of values (total)

Number of families

Number of comparisons per family

Alpha

\section{Dunnett's}

c vs. 110

c vs. 220

c vs. 330

c vs. 440

c vs. 550

c vs. 660

c vs. 770

Test details

c vs. 110

c vs. 220

c vs. 330

c vs. 440

c vs. 550

c vs. 660

c vs. 770

\section{comparisons test}

24

1

0.0

Mean Diff.

-11.48
5.825

5.825
28.13

37.61

34.86

45.99

50.58

Mean 1 Mean 2 Mean Diff.

$\begin{array}{lll}100 & 111.5 & -11.48\end{array}$

$\begin{array}{lll}100 & 94.17 & 5.825\end{array}$

$\begin{array}{lll}100 & 71.87 & 28.13 \\ 100 & 62.39 & 37.61\end{array}$

$\begin{array}{lll}100 & 62.39 & 37.61 \\ 100 & 65.14 & 34.86\end{array}$

$\begin{array}{lll}100 & 65.14 & 34.86 \\ 100 & 54.01 & 45.99\end{array}$

$\begin{array}{lll}100 & 49.42 & 50.58\end{array}$
$D: 440 \quad$ E $: 550$

113.8

$<0.0001$

Yes

0.9803

$\begin{array}{lll}\text { MS } & \text { F (DFn, DFd) } & \text { P value } \\ 1575 & \mathrm{~F}(7,16)=113.8 & \mathrm{P}<0.0001\end{array}$

$\mathrm{F}(7,16)=113.8$

\begin{tabular}{llllll}
$\mathbf{9 5 . 0 0 \%}$ CI of diff. & Significant? & Summary & \multicolumn{2}{l}{ Adjusted P Value } & H-? \\
-20.36 to -2.593 & Yes & $* *$ & 0.0091 & A & 110 \\
-3.058 to 14.71 & No & ns & 0.2967 & B & 220 \\
19.24 to 37.01 & Yes & $* * * *$ & 0.0001 & C & 330 \\
28.72 to 46.49 & Yes & $* * * *$ & 0.0001 & D & 440 \\
25.98 to 43.75 & Yes & $* * * *$ & 0.0001 & E & 550 \\
37.11 to 54.88 & Yes & $* * * *$ & 0.0001 & F & 660 \\
41.7 to 59.46 & Yes & $* * * *$ & 0.0001 & G & 770
\end{tabular}

APPLIED ECOLOGY AND ENVIRONMENTAL RESEARCH 18(1):1301-1315.

http://www.aloki.hu • ISSN 15891623 (Print) • ISSN 17850037 (Online)

DOI: http://dx.doi.org/10.15666/aeer/1801_13011315

(c) 2020, ALÖKI Kft., Budapest, Hungary 